\title{
Contributing towards efforts to abandon female genital mutilation/cutting in Kenya: A situation analysis
}

\author{
Humphres Evelia \\ Population Council \\ Maryam Sheikh Abdi \\ Population Council \\ Carolyne Njue \\ Population Council \\ Ian Askew \\ Population Council
}

Follow this and additional works at: https://knowledgecommons.popcouncil.org/departments_sbsr-rh

Part of the Demography, Population, and Ecology Commons, Family, Life Course, and Society Commons, Gender and Sexuality Commons, International Public Health Commons, Obstetrics and Gynecology Commons, Public Health Education and Promotion Commons, and the Women's Health Commons

How does access to this work benefit you? Let us know!

\section{Recommended Citation}

Evelia, Humphres, Maryam Sheikh Abdi, Carolyne Njue, and lan Askew. 2007. "Contributing towards efforts to abandon female genital mutilation/cutting in Kenya: A situation analysis." Nairobi: Ministry of Gender, Sports, Culture and Social Services, Republic of Kenya. 


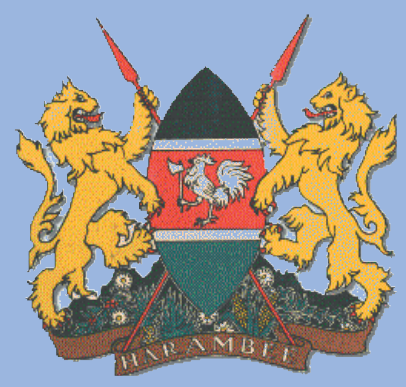

Republic of Kenya

Ministry of Gender, Sports,

Culture and Social Services

Department of Gender \& Social Services

\section{Contributing towards efforts to abandon Female Genital Mutilation/Cutting in Kenya}

A Situation Analysis 


\title{
Contributing towards efforts to abandon Female Genital Mutilation/Cutting in Kenya
}

\author{
A situation analysis
}

Humphres Evelia, Programme Officer, Population Council Maryam Sheikh, Programme Officer, Population Council Carolyne Njue, Research Consultant, Population Council Ian Askew, Representative, Population Council

On behalf of the

Ministry of Gender, Sports, Culture and Social Services

October 2007

This report was made possible through support provided by the UNFPA through Special Service Agreement 22/2006 with the Population Council. The opinions expressed herein are those of the authors and do not necessarily reflect the views of UNFPA. 


\section{ACRONYMS AND ABBREVIATIONS}

\begin{tabular}{|c|c|}
\hline AIC & African Inland Church \\
\hline ARP & Alternative Rite of Passage \\
\hline $\mathrm{CBO}$ & Community Based Organizations \\
\hline $\mathrm{CDF}$ & Constituency Development Fund \\
\hline CEDAW & $\begin{array}{l}\text { Convention on the Elimination of All Forms of Discrimination against } \\
\text { Women }\end{array}$ \\
\hline CIDA & Canadian International Development Agency \\
\hline COVAW & Coalition on Violence Against Women \\
\hline $\mathrm{DCO}$ & District Clinical Officer \\
\hline $\mathrm{DC}$ & District Commissioner \\
\hline $\mathrm{DCO}$ & District Cultural/Children Officer \\
\hline DDEV & District Development Officer \\
\hline DEO & District Education Officer \\
\hline DHS & Demographic and Health Survey \\
\hline DO & District Officer \\
\hline DPHN & District Public Health Nurse \\
\hline DSDO & District Social Development Officer \\
\hline FC & Female circumcision \\
\hline FGD & Focus Group Discussion \\
\hline FGM & Female Genital Mutilation \\
\hline FGM/C & Female Genital Mutilation /Cutting \\
\hline FHI & Family Health International \\
\hline FHOK & Family Health Options of Kenya \\
\hline FIDA & Federation of Women Lawyers \\
\hline FPAK & Family Planning Association of Kenya \\
\hline GCN & Girl Child Network \\
\hline GoK & Government of Kenya \\
\hline GTZ & German Technical Co-operation \\
\hline HIV / AIDS & Human Immunodeficiency Virus / Acquired Immunodeficiency Syndrome \\
\hline HTP & Harmful Traditional Practices \\
\hline & Inter African Committee \\
\hline ICPD & International Conference on Population and Development \\
\hline & Information Communication Technology \\
\hline & Information, Education and Communication \\
\hline
\end{tabular}




$\begin{array}{ll}\text { IPPF } & \text { International Planned Parenthood Federation } \\ \text { IT } & \text { Information Technology } \\ \text { ITCW } & \text { International Technical Committee Workshop } \\ \text { KNCTP } & \text { Kenya National Committee on Traditional Practices } \\ \text { MCC } & \text { Muslim Consultative Council } \\ \text { MCH } & \text { Maternal and Child Health } \\ \text { MoE } & \text { Ministry of Education } \\ \text { MoH } & \text { Ministry of Health } \\ \text { MDGs } & \text { Millennium Development Goals } \\ \text { MYWO } & \text { Maendeleo Ya Wanawake } \\ \text { MP } & \text { Member of Parliament } \\ \text { NFP } & \text { National Focal Point } \\ \text { NGO } & \text { Non Governmental Organization } \\ \text { OCPD } & \text { Officer Commanding Police Division } \\ \text { PATH } & \text { Programme for Appropriate Technology in Health } \\ \text { REM } & \text { Research, Evaluation and Monitoring } \\ \text { RPA } & \text { Rites of Passage Approach } \\ \text { RWPL } & \text { Rural Women's PEACE Link } \\ \text { SNV } & \text { Netherlands Development Organization } \\ \text { STD } & \text { Sexually Transmitted Disease } \\ \text { SUPKEM } & \text { Supreme Council of Kenyan Muslims } \\ \text { TBA } & \text { Traditional Birth Attendant } \\ \text { TP } & \text { Traditional Practitioners } \\ \text { UNIFEM } & \text { United Nations Development Fund for Women } \\ \text { UNDP } & \text { United Nations Development Programme } \\ \text { UNFPA } & \text { United Nations Population Fund } \\ \text { UNICEF } & \text { United Nations Children's Fund } \\ \text { USAID } & \text { United States Agency for International Development } \\ \text { VEP } & \text { Village Empowerment Program } \\ \text { WHO } & \text { World Health Organization } \\ \text { Woman Kind of Kenya }\end{array}$

ii Contributing towards efforts to abandon female genital mutilation/cutting in Kenya: A situation analysis 


\section{TABLE OF CONTENTS}

Acronyms and Abbreviations ........................................................................... i

Acknowledgements......................................................................................... vi

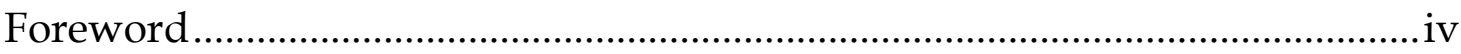

Executive Summary …………………...............................................................vii

Background to the Study ........................................................................... 1

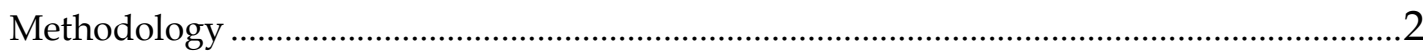

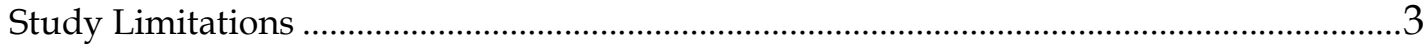

Prevalence of and Trends in FGM/C in Kenya .................................................. 4

Other Emerging Trends ...................................................................................................

Reasons for supporting the continuation of FGM/C........................................ 6

Efforts to encourage abandonment of FGM/C in Kenya ................................... 7

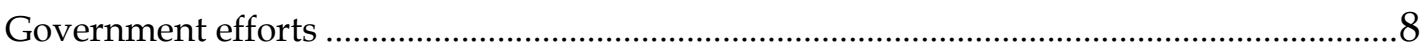

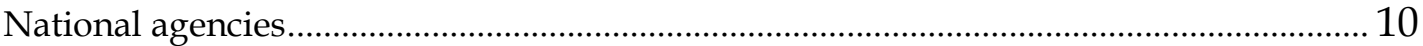

Development partners ……………………………………………………………... 11

Anti-FGM/C approaches used in Kenya ........................................................................ 12

Programming strategies for encouraging behaviour change ............................................... 18

Summary of challenges encountered by anti-FGM/C programmes ................ 22

Lessons learned about FGM/C programming...................................................... 23

Gaps in knowledge and programming …………........................................... 24

Coordinating FGM/C programming support in Kenya .................................... 26

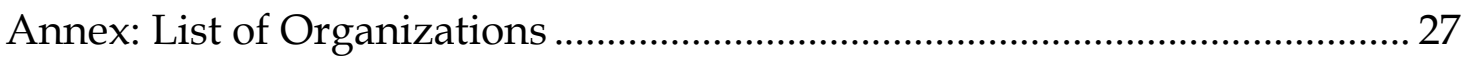




\section{FOREWORD}

The government recognizes that FGM/C is a violation of women's rights and therefore contrary to the "international and regional human rights instruments that Kenya is party to. In upholding these obligations, the government underscores the principles of equality and non-discrimination through multi-sectoral partnerships with the objective of addressing FGM/C in a focused manner.

According to the 2003 Kenya Demographic and Health Survey (KDHS), FGM/C is practiced widely in many Kenyan communities and the prevalence rates vary among the different ethnic and geographical areas in Kenya. For example, among the Kisii, Masai, Somali and Kuria prevalence rates are above $90 \%$ while rates of less than $1 \%$ were reported among the Luo and Luhya. Overall 32\% of Kenyan women are circumcised down from $38 \%$ in 1998. The result of this survey also confirmed that the practice has declined among younger girls with $25 \%$ prevalence among women 20-24 years and 20\% prevalence among 15-19 year olds compared to $48 \%$ prevalence among women $40-49$ years.

Over the years, various interventions have been undertaken with the aim of eliminating the practice. These have been directed mostly towards advocacy for international and national policies against FGM/C, raising public awareness and undertaking small-scale community- based programmes aimed at preventing and eliminating the practice. At the community level, interventions include Alternative Rites of Passage, use of influential community members as agents of change and rescuing girls escaping FGM/C and early marriages. These are supported by several developing partners including GTZ, UNFPA and UNICEF among others.

Implementing partners are also varied and include diverse Community Based Organizations (CBOs), Faith Based Organization (FBOs) and Non-Governmental Organizations (NGOs).

These interventions are however isolated and uncoordinated making it difficult to assess and establish the impact of work being undertaken by the different actors to eliminate the practice. The Ministry of Gender, Sports, Culture and Social Services was mandated as the National Focal point to coordinate activities being undertaken by various actors to eradicate the Practice. To effectively fulfill this role, the Ministry with support from UNFPA commissioned the Population Council to conduct a situation analysis of FGM/C programmes in Kenya. The overall objective of the study was to document the current status and trends of FGM/C and identify the crucial elements that need to be supported in this endeavour. It was also intended to assist in identifying the gaps in the anti.FGM/C programming in Kenya and help identify crucial elements that need to be prioritized for support in this endeavour.

The findings are expected to contribute significantly to the review of the National Action Plan on the Eradication of FGM/C (1999.2019) by including the emerging issues and disseminating the Plan widely to enable stakeholders to enable them utilize it in their programmes.

This study is meant to help us understand and refocus our attention to the political, social, economic and cultural environment surrounding Female Genital Mutilation/Cutting (FGM/C) in Kenya and assist the Government, through the 
Ministry of Gender, Sport, Culture and Social Services, and other stakeholders to identify areas of needs, specific targets, possible partners, adversaries and strategic interventions.

The Ministry of Gender, Sports, Culture and Social Services will continue to work with stakeholders to facilitate implementation of the existing policies and laws to determine the approaches that really contribute to the abandonment of FGM/C.

I therefore urge all stakeholders to ensure that these study findings are utilized to strengthen programmes for anti-FGM/C work in the country. The Ministry of Gender, Sports, Culture and Social Services will continue to provide an enabling environment for the provision of services and programmes aimed at improving the lives of women and girls in Kenya.

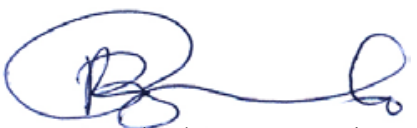

Mrs. Rachel B. Dzombo, CBS

Permanent Secretary

Ministry for Gener, Sports, Culture and Social Services 


\section{ACKNOWLEDGEMENTS}

This report on the Situation Analysis of Female Genital Mutilation/Cutting in Kenya was conducted by Population Council on behalf of the Ministry of Gender, Sports, Culture and Social Services. The Ministry greatly extends its appreciation to all institutions and individuals who contributed in one way or the other to the successful completion of this study.

We greatly acknowledge the financial and technical support from UNFPA in making this study possible. Thanks to Florence Gachanja of UNFPA for her guidance throughout the study and to Ian Askew, Humphres Evelia, Maryam Sheikh (all of Population Council) and Carolyne Njue (Research Consultant) for undertaking the study and preparing this report. Special thanks to Mary Wambua, Mary Kabaru and Department staff for their guidance and coordination of the entire process.

Finally, I thank all development partners, national agencies, community based organizations and individuals who were interviewed for giving their time, ideas and experiences from which this report draws and all research assistants for their dedication and enthusiasm.

It is our hope that all who read this report will endeavour to make good use of the findings for better programming to address FGM/C in Kenya

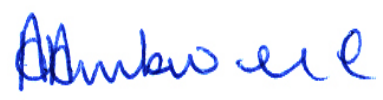

Anne L. Ambwere, MBS

Commissioner for Gender \& Social Services 


\section{EXECUTIVE SUMMARY}

The 2003 Kenya Demographic and Health survey (KDHS) shows that FGM/C is still practiced by the majority of ethnic communities in Kenya. Overall, 32\% of Kenyan women reported being cut in 2003, although this represents a slight reduction compared with $38 \%$ in the 1998 KDHS. Prevalence of the practice varies widely among ethnic groups. The practice is nearly universal among three ethnic groups - the Somali, Abagusii, and Maasai - is highly prevalent among the Taita Taveta, Kalenjin, Embu and Meru, and is still practiced, although to a lesser extent, among the Kikuyu and Kamba. Some ethnic groups in Kenya, notably the Luo and Luhya do not practice FGM/C.

Type of cutting also varies by ethnic group. For example, clitoridectomy is practiced by the Abagusii and kikuyu, excision by the Meru and Maasai, and infibulation by the Somali, Borana, Rendille, and Samburu. The country hosts over 240,000 refugees, mainly from Sudan and Somalia but also from Ethiopia and Eritrea, and these ethnic groups practice type II or infibulation.

The Ministry of Gender, Sports, Culture and Social Services (MGSCSS) has been mandated to be the coordinating body, or National Focal Point, for all ministries within the Government of Kenya as well as for Non Government Organizations (NGOs) and donors working towards abandonment of FGM/C in Kenya. To effectively play this role, the Ministry, with support from UNFPA/Kenya, commissioned the Population Council to conduct a situation analysis of FGM/C programmes in Kenya, with the overall objective of documenting the current status of and trends in FGM/C programming in Kenya and to help identify crucial elements that need to be prioritized for support. The situation analysis used three strategies to collect data: literature review of existing programs, documents and studies on FGM/C, analysis of programs and the national and regional levels and community perceptions collected using qualitative techniques. The study was national in coverage selecting at least one district in seven provinces.

Results show that marked declines in prevalence nationally between generations, suggesting a decline in the practice in recent years (KDHS 2003). There are also trends towards "medicalization," cutting girls at earlier ages and less tissue being cut compared to the past. The practice still continues for different reasons, such as rite of passage, for marriageability, controlling sexuality, religious requirements, and family honour and for cultural and ethnic identify.

Different approaches have been used by different agencies at local and national level to encourage abandonment of the practice. Some of the These include health risk/traditional practice approach, addressing health complications, educating traditional circumcisers and offering alternative income, the alterative right of passage approach, religious oriented approach, legal approach, human rights approach, the intergenerational dialogue approach, promotion of girl's education to appose FGM/C, and supporting girls escaping from early marriage and FGM/C. These approaches use a variety of behavior change channels. Some use traditional communications strategies such as poems and folklore, community education, advocacy, youth participation, research, integrated strategies, educational materials and counseling of survivors. 
From the situation analysis, it's apparent that:

1. Effective partnerships between groups with complementary expertise, at all stages of the program, facilitate effective and sustainable programmes.

2. Involving stakeholders and beneficiaries in the design, implementation, and evaluation of programmes is critical in order to develop culture-specific approaches that are acceptable.

3. Programme design and implementation should be based on sound formative research among the target communities to ensure that the expected outcomes are clear and activities acceptable and therefore feasible. Culture-specific community entry and education is critical.

4. Creating a change in social norms is the most crucial step for a successful behaviour change strategy.

5. Advocacy for girls' education is a long term strategy that seems to be promising, especially among those cultures that cut their girls later.

6. More efforts should be focused on boys and young men who are the future husbands and fathers of girls likely to be cut.

7. The media plays a crucial role in advocacy and is especially important in campaigning about violence against women generally, but care needs to be taken that appropriate messages are communicated.

8. Well-designed IEC materials can raise awareness and influence attitudes but are not sufficient for behaviour change.

9. Continued prosecution can provide a much-needed jurisprudential basis for the development of the law in the area of FGM/C and can help to reinforce the message that FGM/C is neither trivial nor petty.

10. Health providers at all levels, as well as counsellors and psychologists, must be trained and supported to be able to manage medical and psychological, including sexual, complications arising from cutting in girls and women.

11. The state should domesticate and implement the international conventions that offer protection to women and uphold women's rights.

12. There is need for a national coordinating agency on FGM/C in Kenya 


\section{BACKGROUND TO THE STUDY}

Female Genital Mutilation/Cutting (FGM/C), sometimes known as female circumcision (FC), is a traditional practice performed primarily on girl children, adolescents and sometimes on adult women. The World Health Organization (WHO) estimates that about 130 million women throughout the world have undergone some form of FGM/C, and a further 2 million girls are at risk annually ${ }^{1}$. FGM/C is practiced primarily in 28 countries of sub-Saharan Africa, where national prevalence rates range from 5 percent in the Democratic Republic of Congo to 98 percent in Somalia. The practice is also found in small groups in Asia and the Middle East and among migrant communities in Europe, Australia, Canada and USA ${ }^{2}$.

WHO has identified four types of FGM/C (see box), which in Kenya can be classified two broad categories of FGM/C: types I and II which involve the cutting or removal of the entire clitoris, and in most cases, the adjacent parts of the labia minora (small lips) and sometimes all of the external genitalia, except parts of the labia majora (large lips). This is the most prevalent type of female genital cutting in Africa, including Kenya. The other category is type III, known as infibulation, which is the most severe form of FGM/C in which the entire clitoris and labia minora are cut away and the labia majora are thinly sliced or scraped and the raw surfaces either stitched together or sealed. This is practised in Sudan, Somalia, parts of Ethiopia, Southern Egypt, and by some groups in northern Kenya, as well as in some parts of West Africa such as Mali.
$\mathrm{WHO}^{1}$ has classified four types of FGM/C

Type I: Excision of the prepuce with or without excision of part or of all of the clitoris.

Type II: Excision of the clitoris with partial or total excision of the labia minora.

Type III: Excision of part or all of the external genitalia and stitching/narrowing of the vaginal opening. This operation is meant to obliterate the entrance of the vagina leaving a small opening to allow urine and later menstrual blood to escape.

Type IV: Unclassified forms of female genital cutting or modification which includes piercing or incising of the clitoris and/or labia; cauterization by burning of the clitoris and surrounding tissue; scraping of tissue surrounding the vaginal orifice (angurya cuts) or cutting of the vagina (gishiri cuts); introduction of corrosive substances or herbs into the vagina to cause bleeding or for the purpose of tightening or narrowing it; and any other non-therapeutic operations intended to cause harm to the female genitalia with a few of prohibiting sexual intercourse and/or maintaining virginity.

The practice of FGM/C has been condemned internationally, and within Kenya, as a violation of many girls and women's basic rights 3 . In 1979, WHO identified FGM/C as a serious threat to the health of women, especially in the sub-Saharan Africa region. By 1982, WHO had issued a statement on FGM/C stating its commitment to support national governments efforts aimed at eradicating the practice. The 1994 International Conference on

\footnotetext{
${ }^{1}$ World Health Organization (WHO) 2000. Female Genital Mutilation, Fact sheet No. 241

2 WHO (1998) Female Genital Mutilation: An Overview. Geneva: WHO; Population Reference Bureau (2001) Abandoning female genital cutting: Prevalence, attitudes and efforts to end the practice, Washington, DC: PRB

${ }^{3}$ The Universal Declaration of Human Rights of the Child (1948), World Conferences on Women, Copenhagen (1980), Nairobi, 1985, Beijing, 1995; World Conference on Human Rights, Vienna, 1993, International Conference on Population and Development, Cairo, 1994, the World Summit for Social Development, 1995, United Nations Declaration on Violence against Women, Convention on the Elimination of all Forms of Discrimination against Women (CEDAW), Convention on the Rights of the Child (CRC) and the International Day of Zero Tolerance of FGM/C/C, 2005.
} 
Population and Development (ICPD) and the Fourth World Conference on Women in 1995 gave further impetus to international campaigns against FGM/C. In April 1997, WHO, UNICEF and UNFPA issued a joint statement ${ }^{4}$ of their commitment to supporting national organizations, governments and communities to promote abandonment of FGM/C.

Within Kenya, the Ministry of Gender, Sports, Culture and Social Services (MGSCSS) has been mandated to be the coordinating body, or National Focal Point, for all ministries within the Government of Kenya as well as for Non Government Organizations (NGOs) and donors working towards abandonment of FGM/C in Kenya. To effectively play this role, the Ministry, with support from UNFPA/Kenya, commissioned the Population Council to conduct a situation analysis of FGM/C programmes in Kenya, with the overall objective of documenting the current status of and trends in FGM/C programming in Kenya and to help identify crucial elements that need to be prioritized for support.

The specific objectives of the study were to:

1. Describe the variety of social, political, cultural, and religious reasons for the practice and the trends and prevalence across all ethnic groups in Kenya.

2. Identify key FGM/C behaviour change strategies and how they function in different contexts and the most promising approaches, drawing from evidence in Kenya and other countries.

3. Identify major efforts to promote abandonment of FGM/C currently being implemented in Kenya.

4. Describe and assess selected anti-FGM/C activities in a representative sample of districts.

5. Identify key knowledge gaps that may require research to improve understanding of the practice and/or activities to promote its abandonment and management.

6. Recommend coordination roles, implementation structures and procedures that will enable the Ministry of Gender to fulfil its role as national FGM/C focal point.

\section{Methodology}

The following strategies were used to address these objectives:

Literature review: The review sought to understand the political, social, cultural and economic environment related to the practice, the reasons for the practice and trends in the practice over time, key intervention strategies and approaches that have been used against the practice, current knowledge gaps and research needs. Information was obtained from searches through electronic database searches, existing research reports (conducted at national and at community level), project documentation such as reports, evaluations, information and educational materials, and government policy and legislative documents.

Analysis of programmes: In-depth interviews were conducted with key managers of international and local agencies involved in large-scale anti-FGM/C initiatives, both at the national and district level, to capture their experiences with strategies, funding and implementation of the programmes. Their views on the role of the National Focal Point and how it can coordinate anti-FGM/C activities were also sought.

${ }^{4}$ WHO 1997. Female Genital Mutilation: A Joint WHO/UNICEF/UNFPA statement 
Community perceptions: In-depth interviews were conducted with key stakeholders such as relevant government officials (children's officers, social workers, the police etc. at both national and district levels), and focus group discussions (FGDs) were held with community gatekeepers (including religious leaders, chiefs, other opinion leaders, parents, teachers and health providers).

Primary data were transcribed and processed using the NUDIST computer programme for analyzing qualitative data. An index coding system was developed to summarize themes to address the key research questions.

The study was national in coverage, through selecting at least one district in seven provinces. Districts were selected to include not only a range of ethnic groups that practice FGM/C for different reasons, but also to ensure that a wide variety of programmatic strategies were sampled. Table 1 lists the districts and ethnic groups included in the study.

Table 1: Districts and Ethnic groups sampled

\begin{tabular}{|l|l|l|}
\hline Province & District & Ethnic groups \\
\hline Coast & Tana River, Taita/Taveta & Orma, Boni Malakote, Wardey \\
\hline North Eastern & Garissa, Isiolo & Somali \\
\hline Eastern & Marsabit & Rendille, Samburu, Gabra \\
\hline & Meru & Meru \\
\hline Central & Nyandarua, Nakuru & Kikuyu \\
\hline Rift Valley & Narok & Maasai \\
\hline & Mt. Elgon & Sabaot, Sabei \\
\hline Nyanza & Kuria & Kuria \\
\hline & Kisii, Gucha & Kisii \\
\hline Nairobi & Eastleigh & Somali \\
\hline
\end{tabular}

\section{Study Limitations}

The study was limited in terms of the time available, which constrained the scope and depth of the analysis, and the number of projects that could be included. Moreover, the widely varying nature of the strategies and projects assessed, and the quality of information collected created difficulties in analysis and presentation A substantial number of potential respondents were on annual leave at the time of data collection (December 2006), and some parts of the country experienced heavy rains and flooding, reducing access to some districts (e.g. Tana River, Garissa and Isiolo). 


\section{PreVAlenCe OF AND TRENDS In FGM/C IN KenYA}

The 2003 Kenya Demographic and Health survey (KDHS) ${ }^{5}$ shows that FGM/C is still practiced by the majority of ethnic communities in Kenya. Overall, 32\% of Kenyan women reported being cut in 2003, although this represents a slight reduction compared with $38 \%$ in the 1998 KDHS. Prevalence of the practice varies widely among ethnic groups. The practice is nearly universal among three ethnic groups - the Somali, Abagusii, and Maasai - is highly prevalent among the Taita Taveta, Kalenjin, Embu and Meru, and is still practiced, although to a lesser extent, among the Kikuyu and Kamba. Some ethnic groups in Kenya, notably the Luo and Luhya do not practice FGM/C.

Type of cutting also varies by ethnic group. For example, clitoridectomy is practiced by the Abagusii, excision by the Meru, Kikuyu and Maasai, and infibulation by the Somali, Borana, Rendille, and Samburu. The country hosts over 240,000 refugees, mainly from Sudan and Somalia but also from Ethiopia and Eritrea, and these ethnic groups practice type II or infibulation.

Age of cutting varies also by ethnic group, and is usually determined by the meaning associated with the practice. For those that practice FGM/C as a rite of passage to adulthood (e.g. Meru/Embu), cutting is normally undertaken around the age of puberty. For the Maasai and Samburu, who practice FGM/C as a means of denoting that the girl is ready for marriage, cutting is usually undertaken post-puberty, and can often be when the girl is in her late teens immediately prior to marriage; indeed, FGM/C can sometimes form part of the marriage ritual. Although a few circumcise during infancy (e.g. Taita), several ethnic groups practice FGM/C pre-puberty, between ages 6 - 10 years (e.g. Somali, Kisii, Borana) because bleeding is minimal, the tissue is soft to cut, the wound is thought to heal faster and the young girls are easier to handle during the process as they are keen to be socially accepted and do not always understand the implications ${ }^{6}$.

There are indications of changes in the way FGM/C is practised in several communities. The KDHS 2003 data suggests marked declines in prevalence have occurred nationally between generations, suggesting a decline in the practice in recent years (see Figure 1 below). The proportion of women cut decreases steeply with age, from nearly one-half of women age 35 years and above, to one quarter of those aged 15-19 years. These declines are particularly pronounced among the Kalenjin (62\% to $49 \%$ ), Kikuyu (43\% to 33\%) and Kamba (33\% to $27 \%)$.

${ }_{5}$ Central Bureau of Statistics (CBS) [Kenya], Ministry of Health (MOH) [Kenya], and ORC Macro. 2004. Kenya Demographic and Health Survey 2003. Calverton, Maryland: CBS, MOH, and ORC Macro.

6 See Jaldesa G. 2002. "Reasons for the practice and health problems associated with female genital mutilation: Evidence from four communities in Northern Kenya," Unpublished report for Action Aid, North East region, Kenya; Jaldesa G., Z. Qureshi, C. Kigondu , and S. Wanjala. 1998. "Factors enhancing the practice of FGM among the Kenyan Somalis," Journal of Obstetrics and Gynaecology, East and Central Africa, 14(2): 110-114 
Figure 1: Prevalence of FGM/C among women aged 15-49 years in Kenya by age group

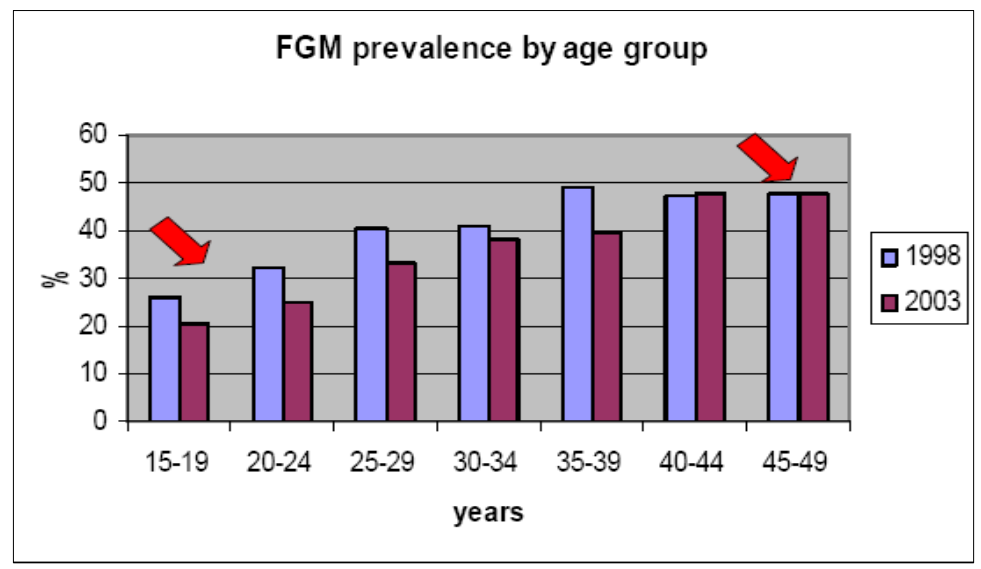

\section{Other Emerging Trends}

Literature on FGM/C indicates a trend towards girls being cut at earlier ages and less cutting than in the past ${ }^{7}$. Girls are most frequently between seven to 12 years old compared to $12-15$ years before. There are also reports that the amount of tissue cut is reducing. A recent study among the Somali, for example, shows that all participating women and girls had been cut, and most were infibulated, though a gradual decline in the severity of the cut among younger girls, from infibulation to a less severe form, was reported ${ }^{8}$. Among the Nandi, clitoridectomy is more prevalent among younger women whereas excision is more prevalent in the older age groups ${ }^{9}$.

Studies also show an increasing trend toward the "medicalization" of FGM/C, as more girls reporting being cut by medical professionals rather than by traditional practitioners ${ }^{10}$. According to the 1998 KDHS, one-third of all women who had undergone FGM/C reported being cut by a health worker. A Population Council study in 2001 found that 70 per cent of cut Abagusii girls in Nyanza Province reported having been cut by a nurse or doctor, whereas virtually all of their mothers had been cut by a traditional circumciser ${ }^{11}$. In another

\footnotetext{
7 See Yoder, P. Stanley, Noureddine Abderrahim, and Arlinda Zhuzhuni. 2004. Female Genital Cutting in the Demographic and Health Surveys: A Critical and Comparative Analysis. DHS Comparative Reports No 7. Calverton, Maryland: ORC Macro. Chege, J., I. Askew and J. Liku. 2001. An assessment of the alternative rites approach for encouraging abandonment of female genital mutilation in Kenya, FRONTIERS Final Report. Nairobi, Kenya: Population Council; PATH (1996) Kenya: Focus Group Discussion from Three Districts. Washington, DC: PATH; UNICEF/PATH. 1998. "Research in Five Districts of Kenya: Female Genital Cutting", Unpublished report, PATH/Kenya, Nairobi, Kenya; Bettina Shell-Duncan and Ylva Hernlund, 2000. Female "Circumcision" in Africa: Culture, Controversy, and Change (Boulder, CO: Lynne Rienner Publishers, Inc.)); Njue, C. and I. Askew. 2004. Medicalization of Female Genital Cutting among the Abagusii in Nyanza Province, Kenya, Population Council: Nairobi, Kenya

8 See Jaldesa, G. W., I. Askew, C. Njue, and M. Wanjiru. 2005. Female genital cutting among the Somali of Kenya and management of its complications, FRONTIERS Final Report. Nairobi, Kenya: Population Council
}

${ }^{9}$ Maendeleo Ya Wanawake (1992) Traditional Practices that affect the health of women and children. Nairobi: Maendeleo ya Wanawake (Unpublished Report)

10 See Yoder, P. Stanley, Noureddine Abderrahim, and Arlinda Zhuzhuni. 2004; Njue, C. and I. Askew. 2004; Shell-Duncan, Bettina, W. O. Obiero, and L. A. Muruli. 2000. “Women without choices: The debate over medicalization of female genital cutting and its impact on a Northern Kenyan community," in Bettina ShellDuncan and Ylva Hernlund (eds.), Female "Circumcision" in Africa: Culture, Controversy and Change. Boulder, Colorado: Lynne Rienner Publishers, Inc., pp. 109-128.

11 Chege, J., I. Askew and J. Liku. 2001. 
study, the proportion of cut women reporting that the cutting was done in a health facility increased from 5 percent in 1993 to 23 percent in 200012. Evidence has now been published about the health-related complications of FGM/C and guidelines issued for obstetrical and gynaecological care for women having undergone $\mathrm{FGM} / \mathrm{C}^{13}$. Criminalization of the practice has also led to fewer women willing to seek proper medical care when they suffer complications. Due to the existence of legislation that prohibits FGM/C, many communities are leaving out the ceremonial aspects of the practice $^{14}$.

\section{REASONS FOR SUPPORTING THE CONTINUATION OF FGM/C}

Rite of passage: For several Kenyan communities (e.g. Meru, Embu, Maasai, Kalenjin), FGM/C is considered a rite of passage through which important cultural values and adult expectations are transmitted to the youth. Girls who have not undergone FGM/C are often ridiculed, made to feel ashamed, and addressed as children ${ }^{15}$.

Ensure marriageability: Families of girls or women among the Samburu support cutting because it makes their daughters not only marriageable but able to attract high bride price. Among the Maasai community, marriage is an important factor to girls' life as it assures the girl of a home, it is important for the continuation of the family tree. Maasai men feel honoured if they marry a circumcised girl, and this tradition has made it difficult to abandon the practice. According to the elders, those who are campaigning against FGM/C cannot be elected as leaders (chiefs and councillors) among the Maasai and Samburu community. Women also believe that a marriage is not complete unless the mother cuts her daughter and prepares her for marriage. In other communities, such as the Kuria and Kisii, uncut girls are considered as children. Among the Kuria, the girls are referred to as "kunene", a derogatory term making it difficult for them to be married.

Family honour: Among the Somali, it is believed that a family that fails to circumcise its daughters risks losing respect and its members may be ostracized to become outcasts. This is because of the great importance and value that they attach to virginity and marriage. The virginity of a bride, usually ascertained by the narrowness of the vagina after infibulation, attracts a high bride price. This is also similar in other communities and no father would fail to subject his daughter to the practice in order to attract a high bride price. FGM/C is said to confer on girls and women a new identity; they are presumed to become virgins ${ }^{16}$. Women who do not circumcise their daughters run the risk of being seen as irresponsible, immoral and imitators of Western culture. These sentiments are common among other groups such as the Meru, Kalenjin and Abagusii.

Controlling sexuality: Cutting and stitching a girl's genital organ is thought by many ethnic groups to suppress her sexual desires, as a way of keeping her from having sex for pleasure,

\footnotetext{
$12 \mathrm{PATH} / \mathrm{MYWO}$. 2000. Final evaluation report on eliminating the practice of FGM: Awareness raising and community change in four districts of Kenya. Nairobi: PATH/Kenya.

${ }^{13}$ A Systematic Review of the Health Complications of FGM, including Sequelae in Childbirth. Geneva 2000b; Toubia, N. Caring for Women with Circumcision. Rainbo, New York 1999; Mwangi-Powell, F. FGM: Holistic Care for Women. A Practical Guide for Midwives. FORWARD, London 2001.

${ }^{14}$ UNICEF .2005. Changing a harmful social convention: Female Genital Mutilation, Innocenti Research Centre

15 Gwako, E. L. Moogi (1995) “Continuity and Change in the Practice of Clitoridectomy in Kenya: A Case-Study of the Abagusii" vol 33 No.2 The Journal of Modern African Studies 333-7

16 Van der Kwaak, A (1992) "Female Circumcision and Gender Identity: A Questionable Alliance?" Social Science and Medicine 35: 777-797
} 
before, during or outside of marriage. The Abagusii believe that a circumcised woman will not want to have pre-marital or extra-marital sex because she will not have a strong sexual drive. Uncut women are thought to be easily aroused and possess strong sexual desires which are not culturally acceptable ${ }^{17}$. In some communities such as the Somali, after giving birth or after a divorce and before remarrying, a woman may be re-infibulated to enhance the husband's sexual pleasure ${ }^{18}$. The main reason behind FGM/C, according to elders from Isiolo, was to reduce the libido of the girls, enforce the cultural value of sexual purity / virginity until marriage.

Religious requirement: Some communities practice FGM/C because they believe it is a religious requirement. The Somali, Borana, Orma, Wardey and Boni believe that FGM/C constitutes an Islamic sunnah practice, that is, the prepuce covering the clitoris should be removed. This is because prayers of uncircumcised persons (males or females) are considered unacceptable. The clitoris is considered haraam (dirty or not pure in the sense of religious purity and cleanliness) thus it must be removed ${ }^{19}$.

Cultural and ethnic identity: Most ethnic groups that practice FGM/C in Kenya (i.e. the Swahili/Mijikenda, Kamba, Kikuyu, Meru, Embu, Kalenjin, Taita Taveta, Maasai, Abagusii and the Somali) consider it a deeply rooted cultural practice. Many participants in the FGDs indicated that the reason for mothers to circumcise their daughters was because their grandmother did so, and so their daughters have to undergo the same.

\section{EFFORTS TO ENCOURAGE ABANDONMENT OF FGM/C IN KENYA}

Anti-FGM/C efforts in Kenya are not new; they date back as early as the 1900s, when the colonial authorities and missionaries attempted to stop the practice by promulgating criminal regulations and using religious propaganda ${ }^{20}$. But these activities did not succeed due to cultural and nationalist resistance ${ }^{21}$. In the end, the colonial authorities abandoned the idea of using criminal law to prevent FGM/C, turning instead to education and propaganda and whatever administrative action could be undertaken with the assistance of the indigenous authorities. Meanwhile some nationalist politicians glorified FGM/C in the struggle for independence in the 1950s 22 .

As Kenya headed for full statehood, the colonial authorities rescinded all public policy measures outlawing FGM/C on the grounds that the practice was a deeply rooted and acceptable custom in the affected communities. In independent Kenya, attempts to prevent FGM/C were revived from the early 1980s by church leaders. Post independence, the fight

17Momanyi Mokoya (2001). Female Circumcision amongst the Abagusii People in Kenya: African Herald Publishing House

18 Van der Kwaak, op cit.

${ }^{19}$ Lovel H., N. Bedri, Z. Mohamed, Y. Njikam, R. Moran, C. McGettigan, M. Khaled, M. Magied, and E. Dorkenoo. 2004. "The practice of re-infibulation in the Sudan: Findings from a systematic search of English and Arabic Literature", Paper

20 Thomas, L (1992) “Customs, Colonial Economics and the Constitution of Authority: Administrative Interventions in the Practices of Excision and Abortion in Meru District, Kenya 1908 - 38 No.70 Research Seminar Paper, Northwestern University; Chege, Jane (1993) The Politics of Gender and Fertility Regulation in Kenya: A case study of the Igembe, Ph.D Thesis, Lancaster University.

21 Thomas, L. (1998) "Imperial Concerns and Women's Affairs": State Efforts to Regulate Clitoridectomy and Eradicate Abortion in Meru, Kenya" Volume 39 Journal of African History 121 - 145

22 Kenyatta, Jomo (1938) Facing Mt. Kenya. London: Secker and Warburg; Thomas, 1997 
against FGM/C in Kenya has received support from various levels: internationally through policy dialogue and funding, active commitment and involvement of government ministries, religious groups, international and local non-governmental organizations, United Nations agencies, and at the community level.

\section{Government efforts}

The Government of Kenya, through several ministries (Education, Health, Gender, Culture and Social Services, Home Affairs, Natural Heritage, Information and Broadcasting, Justice, Planning), and through local authorities, has been instrumental in efforts to encourage abandonment of FGM/C. Presidential decrees have been issued in 1982, 1989, 1998 and 2001 by former president Daniel Moi ${ }^{23}$. For example, in 1982, President Moi issued a decree against the practice; individuals who went against this decree could be prosecuted in a court of law under the Chief's Act of 191224. Despite the existence of the Chief's Act, there was no legal provision for persons who continued to undertake the rite ${ }^{25}$. In 1989 President Moi called for an end to the practice and six months later the Assistant Minister for Culture and Social Services announced an official government ban on the practice ${ }^{26}$. The Director of Medical Services followed, forbidding medical personnel from carrying out the procedure, stating that he would prosecute medical professionals performing FGM/C under the Medical Practitioners and Dentists Act and the Nurses, Midwives and Health Visitors Act.

Sections 74, 250, and 251 of the current national constitution protect every individual from torture and inhuman and degrading treatment, and have been used to argue that FGM/C should be seen as an unlawful practice. Government efforts are also evident in key policy guidelines and legal provisions. The Sessional Paper No. 5 of 1999 on the National Population Policy for Sustainable Development recognizes that FGM/C is a harmful cultural practice. In 1999, the Government approved the National Plan of Action (NPA) for the Elimination of FGM/C in Kenya, developed by the MOH with support from WHO. The plan sets out the goal, broad objectives, strategies, targets and indicators for accelerating the elimination of FGM/C. This NPA has provided a framework within which all players in the country are expected to organize their anti-FGM/C efforts.

Moreover, by ratifying international legal instruments and conventions that condemn FGM/C27, Kenya accepts that FGM/C is a violation of the human rights of women and girls, and thereby agrees to an international obligation to end the practice. The Fourth World Conference on Women in Beijing was an important impetus to the Government, NGOs, women's organizations and civil society in general to identify major concerns for women and adopt strategies, for both Government and NGO agencies. The resolutions of the 47th World Health Assembly to "establish national policies and programs that will effectively,

\footnotetext{
${ }^{23}$ Nairobi Times (1982) "President Moi Bans Female Circumcision in Kenya." The Nairobi Times, Monday, September 6 , Nairobi, Kenya; Stop Girl Circumcision: D.T. Moi; Kenya Times of December 1998.

${ }^{24}$ Kabeberi-Macharia, 1995 Female Genital Mutilation and the Rights of the Girl in Kenya.

${ }_{25}$ Nyasera B.K (1994) Female Circumcision: Its Persistence Among The Somali of Kenya. Nairobi. MA Thesis, Institute of African Studies, University of Nairobi.

${ }^{26}$ Anika R. and Nalieb, T. (2000). Female Genital Mutilation: A Guide to Laws Policies Worldwide.

27The subjection of women and girls to FGM/C/C is considered an act of control and denial of basic human rights that compromise the enjoyment of their fundamental rights: the right to physical and mental health, the right to be free from gender discrimination, the right to life and to freedom from torture including the inherent dignity of the person, the right to liberty and security of person, and the right to privacy. See Rahman and Toubia, 2002.
} 
and with legal instruments, abolish FGM/C" was also adopted. Kenya has also adopted the Millennium declaration which outlines peace, security, development concerns including environment, human rights, and governance ${ }^{28}$.

The Kenyan Parliament has also enacted the Children Act (No. 8 of 2001) which criminalizes FGM/C on children below 18 years. Section 14 of the Act provides that "no person shall subject a child to female circumcision, early marriage or other cultural rites, customs or traditional practices that are likely to negatively affect the child's life, health, social welfare, dignity or physical or psychological development". Section 18 of the Act stipulates that any conviction for FGM/C-related offences carries a penalty of 12 months imprisonment and/or a fine not exceeding Kshs 50,000 (approximately US\$710). To these, may be added the provisions of Section 234, 250 and 251 of the Penal Code which criminalize grievous bodily harm. Properly construed, they can be used to penalize FGM/C. Practitioners and parents forcing the procedure on their daughters can also be prosecuted under child abuse laws, or for grievous bodily harm or unlawful dismemberment of an organ of the body. Girls are also increasingly aware of the Act and their right to refuse to be cut - for instance, the two teenage girls who secured a landmark ruling on 13 December 2000, when a magistrate's court issued a permanent injunction barring their father from having them circumcised.

Most recently, the Ministry of Gender has been instrumental in promoting implementation of international agreements that address gender equity generally, and FGM/C specifically. It provides support to the gender desks in various ministries to support them on gender mainstreaming and gender budgeting. In September 2004, Kenya hosted the International Conference on FGM/C entitled "Developing a Political, Legal and Social Environment to Implement the African Union's Maputo Protocol ${ }^{29}$. The government ratified the protocol, joining Libya, Comoros, Rwanda, Namibia, Lesotho and Djibouti.

${ }^{28}$ The Millennium Development Goals, cannot be achieved if sexual and reproductive health and rights are not addressed. It is essential to break the silence and taboos on culture and religion and their relation to reproductive and sexual health and rights, and establish a permanent dialogue on these vital issues.

${ }^{29}$ The Maputo Protocol was adopted on 11 July 2003 as a protocol to the African Charter on People's and Human Rights in Maputo, Mozambique, it covers a broad range of women's rights, including the elimination of discrimination against women, the right to dignity, the right to life, the integrity and security of the person, the right to education and training, economic and social welfare rights and health and reproductive rights. Article 5 of the protocol requires that all forms of female genital mutilation be condemned and prohibited. The protocol requires ratification by 15 countries to enter into force. 


\section{National agencies}

Table 2: Some Organizations Involved in Anti-FGM/C Activities in Kenya, by District

\begin{tabular}{|c|c|}
\hline District & National Organisations \& CBOs \\
\hline Garissa / Isiolo & $\begin{array}{l}\text { CLAN, Care International, UNICEF, Womankind Kenya, Woman Concern, PGI, } \\
\text { SIMAHO, Population Council, WDI, FONI, Northern AID, AL Falal, IYAAP }\end{array}$ \\
\hline Meru & $\begin{array}{l}\text { Plan International, RIPPLE International, Samaritan Purse Relief International, } \\
\text { GTZ, Save the Children Canada, MYWO, Methodist, Anglican Church of Kenya } \\
\text { (ACK), CIWIT, Tigania Cultural Development Association }\end{array}$ \\
\hline $\begin{array}{l}\text { Nyandarua } \\
\text { /Nakuru }\end{array}$ & $\begin{array}{l}\text { KYCDEP, St. Martins, FHOK, AMREF, Action Aid, Child Welfare Association, } \\
\text { MYWO, CDN, PCEA, NCCK, Christian Community Services, PFP, Ogiek } \\
\text { Welfare Community association }\end{array}$ \\
\hline Narok & $\begin{array}{l}\text { Tasaru Girls Rescue Center, CRS, Action Aid, World Vision, CIPED, MYWO, } \\
\text { Full Gospel Church of Kenya, MAIKOO ATE, CCF, Africa Hope, CIPED, CMF }\end{array}$ \\
\hline Mt. Elgon & World Vision, GTZ, KEFEADO, SOET, ACK, Action Aid, NCCK, RWPL \\
\hline Kuria & GTZ, Action Aid, AMREF, Maranatha, SDA, KAACR, ADRA, KCDP \\
\hline $\begin{array}{l}\text { Tana River/ } \\
\text { Taita Taveta }\end{array}$ & CIPK, World Vision, Action Aid, FIDA, VOS, ACFRA, UNFPA, CDA \\
\hline Kisii/ Gucha & $\begin{array}{l}\text { MWYO, ADRA Kenya, Action Aid, Julie K, Lutheran Outreach, CCF, SDA, } \\
\text { WAFNET, ATFC, Vivid Communications, CWS, AMREF, World Relief, MERLIN }\end{array}$ \\
\hline Nairobi & $\begin{array}{l}\text { UNFPA, UNICEF, UNIFEM, USAID, Dfid, GCN, CRADLE, CEDMARC, CLAN, } \\
\text { AMREF, AMWIK, PATH, CREAW, Population Council, CWA, AED, } \\
\text { CEMIRIDE, NCAPD, SNV, Action Aid, SDA Rural Project, GTZ, World Vision, } \\
\text { Catholic Secretariat, FHOK, Health Unlimited, Kenyan Arab Friendship Society, } \\
\text { Northern Aid, IPPF, MWYO }\end{array}$ \\
\hline
\end{tabular}

Local implementing partners are varied and include a collection of community-based organizations, faith based organizations and national non-governmental organizations. In 2002, the National Focal Point (NFP) for FGM/C, a coordinating mechanism hosted by the NGO Northern Aid and supported primarily by UNDP, carried out a desk review of stakeholders and those implementing FGM/C in Kenya ${ }^{30}$. The review found that most national organizations depend heavily on funding from international donors that are interested in addressing FGM/C, especially through prevention activities, lobbying and advocacy. Most of the larger national organizations have programmes covering several districts and targeting different audience segments such as faith led groups, adolescents, married women, men, and communities. Some NGOs have produced training programmes for professionals, developed educational materials, and conducted awareness raising campaigns aimed at different target groups, such as practicing communities, health professionals, the educational system, the police, and the media.

\footnotetext{
30 See Olenja, Joyce M (2002) Female Genital Mutilation in Kenya: A Literature Review, Nairobi: National Focal
} Point 


\section{Development partners}

Many bilateral and multilateral agencies have supported anti-FGM/C activities by these national organizations through funding personnel, materials and equipment such as medicines, vehicles and intellectual resources. Some examples of past and current activities supported by development partners include:

UNFPA supports implementing partners such as SAIDIA in Samburu District, Tasaru Ntomonok Initiative (TNI) in Narok District, the Catholic Diocese of Nakuru (CDN), Archdiocese of Nairobi (ADN) and the Council of Imams and Preachers of Kenya (CIPK), MYWO and FHOK. Additionally, UNFPA works with the Federation of Women Lawyers (FIDA), to enhance capacities of key national and local institutions to formulate, coordinate and manage gender responsive population and $\mathrm{RH}$ policies and programmes. UNFPA also supports the Ministry of Gender, Culture Sports and Social Services as the national FGM/C Focal Point on FGM/C and supports the activities of Kenya Women's Parliamentary Association (KEWOPA), Kenya Media Network (KEWEP), National Coordinating Agency for Population and Development (NCAPD) and Kenya National Bureau of Statistics ( KNBS).

UNIFEM is supporting the review of policies that support women's human rights and campaign against GBV/FGM/C. Partners include the Ministry of Gender, Women Parliamentarians Association (KEWOPA) and the Gender Commission.

WHO has supported the Ministry of Health to develop the National Plan of Action 19992010 for the elimination of FGM/C and launched it in 1999. WHO also supported creation of the National Focal Point (NFP) to coordinate FGM/C ${ }^{31}$ and has funded a number of studies on medical complications ${ }^{32}$.

UNICEF has used the integrated approach in addressing FGM/C issues in North Eastern Kenya within a development context. UNICEF through the African Girls Education Initiative (AGEI) with funding from Governments of Norway, Japan and the Swedish Committee, has made significant inroads into girls' education in Northern Kenya. Positive change in parents and communities attitude towards girls' education is evident with some girls' boarding schools receiving 30\% contributions from them like the case of Turkana and Kalacha in Marsabit district.

The Government of Italy is funding UNICEF/Kenya FGM/C projects in Garissa and Moyale districts, Northern Kenya. UNICEF has partnered with CCM, an international NGO, to implement an FGM/C Project in Moyale District. The projects focus on community interventions including significant work with religious leaders, community members and support to Government ministries. UNICEF also uses community dialogues to encourage debate towards abandonment of the practice. Discussions are held with different segments of the community -men, women, community elders, religious leaders, youth and circumcisers.

The Governments of Germany and Kenya in April 2003 agreed to an eight-year bilateral agreement to encourage abandonment of the practice. Under this agreement, GTZ in collaboration with $\mathrm{MOH}$ have initiated anti-FGM/C projects in different parts of the country including Kajiado and Kuria districts, Greater Meru (Meru North and Tharaka) districts and in North Eastern Kenya in Wajir and Garissa districts including the refugee camps of

${ }^{31} \mathrm{NFP}$ was under the leadership of Northern Aid

32 WHO 1998, op cit. 
Daadab. Among some of the approaches used by GTZ are the Alternative Rights of Passage and the Intergenerational Dialogues to stimulate debate in the community on FGM/C.

The Government of the United States, through USAID, has funded the Program for Appropriate Technology in Health (PATH) to work with MYWO on introducing alternative rites of passage for girls. In the late 1990s, USAID funded Womankind, a local organization working on a variety of women's issues, including FGM/C. In 1998, USAID also made a grant to the Federation of Women's Groups of Nyamira, which trains the community to speak about the dangers of the practice and develops alternative rites of passage for young girls. USAID also supports the Demographic and Health Survey (KDHS) which routinely measures FGM/C prevalence nationally, and worked closely with the Ministry of Health to develop the National Plan of Action for the elimination of this practice. Since July 1999, the U.S. Embassy, through its discretionary grant fund, has funded nine women's workshops on this issue. USAID funded Population Council's studies on understanding the meaning of FGM/C and medicalization of the practice in the Abagusii community and an assessment of the alternative rite of passage. USAID/Kenya is currently funding Population Council to address the management and prevention of FGM/C complications among the Somali community of Kenya.

\section{Anti-FGM/C approaches used in Kenya}

\section{Health risk / harmful traditional practice approach}

The health risk approach has probably been the most widely used rationale globally for efforts to eliminate FGM/C over the past 20 years ${ }^{33}$. Interventions using this approach develop and communicate messages that emphasize the harmful physical effects the practice can have for women (such as haemorrhage, infection, pain, fever, and shock) during the procedure and subsequent complications (such as difficulty in urinating and with sexual intercourse and the risk to mother and child during delivery). An important aspect of this approach is that it can be used to break the silence in a sensitive social and political environment, because it becomes acceptable to talk about FGM/C in these terms in public situations. Nearly all the organizations contacted have a component on the health risks of FGM/C in their programmes and conduct trainings for communities on these messages. Examples include CARE-Kenya, Girl Child Network, CCM-Italy, CRADLE and CREAW.

While a "health risk" message is necessary as part of the awareness raising information delivered to the target group, it is not sufficient by itself to undermine a practice that is based on cultural beliefs and the desire to control women's sexuality and fertility. One major disadvantage of this approach, moreover, is that it seems to have led to a medicalization of the practice, with non-traditional practitioners such as doctors, nurses and midwives being asked to, and actually performing FGM/C, as a logical response by parents who want to sustain the practice but to reduce the harmful effects on their girls' health. In addition, milder forms of FGM/C seem to be performed by medically trained personnel ${ }^{34}$.

33 Toubia, Nahid and E. Sharief (2003) “Female Genital Mutilation: have we made progress?”, International Journal of Gynecology and Obstetrics, 82, 251-261.

34 Njue C, and Askew, I (2004): Medicalisation of Female Genital Cutting among the Abagusii in Nyanza province, Kenya. FRONTIERS Final Report, Nairobi, Kenya: Population Council. 


\section{Addressing the health complications of FGM/C}

Health care providers are also being asked to re-infibulate women after delivery among those groups that practice type III ${ }^{35}$. In response to this, Population Council, with support from USAID, UNICEF and DANIDA, has developed and implemented a training programme with the Ministry of Health throughout North Eastern Province to sensitize and train health care providers not to re-infibulate after delivery, and how to treat and counsel women who are suffering complications from FGM/C, especially during pregnancy and delivery ${ }^{36}$. This approach also orientates health workers to better understand the sociocultural and religious reasons perpetuating the practice and provides them with messages to communicate to their clients and communities. This training will be sustained by GTZ and with support from UNHCR/Kenya, introduced into clinics serving Somali populations in Nairobi.

\section{Educating traditional circumcisers and offering alternative income}

Educating traditional circumcisers about the health risks associated with the practice and/or providing them with alternative means of income to motivate them not to undertake the practice is another long-standing approach. Assessments undertaken elsewhere show that such "conversion" strategies usually include one or more of the following components ${ }^{37}$ :

1) Identifying circumcisers and educating them about the reasons for and problems with FGM/C;

2) Training circumcisers to become change agents and motivating them to educate their community, and specifically families that request FGM/C, about its harmful effects;

3) Orienting them towards and training them in generating alternative sources of income to replace that lost through not undertaking FGM/C.

CIPK in Tana River gives grants for income generation to circumcisers to encourage them to stop cutting girls by getting alternative income from goat keeping. CARE Kenya, in their project in the refugee camps, implemented an alternative income project for circumcisers but had to stop because circumcisers did more cutting for 'free' - indeed, they recorded the highest number of girls cut in the year they disbursed the funds.

Most assessments of this approach have not shown the expected results, as awareness raising and offers of alternative skills and income do not seem sufficient to persuade most circumcisers to stop a practice when there is still a strong demand for it. While such efforts may, at best, encourage a few individual practitioners to stop, they appear to have virtually no effect on demand for the practice. As a result, traditional practitioners tend to return to cutting within a short period of time.

\section{Alternative Rites of Passage (ARP) Approach}

For several ethnic groups in Kenya, such as the Meru, Maasai and Kuria, circumcision has been an integral component of traditional rites of passage initiating girls (and usually boys

\footnotetext{
${ }^{35}$ Jaldesa G W, Askew I, Njue C and Wanjiru M. 2005. Female Genital Cutting among the Somali of Kenya and Management of its Complications. FRONTIERS Final Report, Nairobi, Kenya: Population Council.

36 FRONTIERS (2006) Reproductive Health Update Trainings for Health Workers in North Eastern Province: Training Health Care Providers as Change Agents, FRONTIERS, Nairobi, Kenya: Population Council.

37 Population Council. 1998. Evaluation de la stratégie de reconversion des exciseuses pour l'éradication de MGF au Mali. Bamako. http://www.popcouncil.org/pubasps/Publication; Female Genital Mutilation; WHO. 1999. Programmes to Date: What Works and What Doesn't. A review. World Health Organization, Geneva
} 
too) from childhood to adulthood. As societies attribute great importance to these comingof-age ceremonies, abandoning FGM/C can be associated with abandonment of the rites of passage themselves, which may create considerable social conflict and/or a lack of interest in abandoning FGM/C. Consequently, "it is much more productive to develop new activities to take the place of damaging customs than to prohibit outright what has been done traditionally. The alternative proposed here is to change the contents, stopping the mutilations, while preserving the positive idea". 38 Alternative rituals to mark initiation have been developed to substitute for the traditional cutting ceremonies, comprising traditional education on the role the adolescent girl will be expected to play, including aspects of sexuality and motherhood. Girls are secluded from the rest of the community for days or weeks and receive their education in specially designated places. Such rites are usually the occasion for joyful festivities lasting for days and involving the community as a whole.

The first Alternative Rite of Passage (ARP) was developed by a women's group called Ntanira na Mugambo (NNM), and was celebrated in 1996 in Tharaka Nithi District, where 29 girls were initiated into adulthood. Following this success, PATH and MYWO developed a programme which refined this approach and promoted it among communities in Narok and Gucha districts. By December 1998, 12 ARP ceremonies had been conducted in four districts and 1,124 girls had gone through the ceremony ${ }^{39}$. The alternative ceremonies were well received by most communities and were thought to have reduced the number of adolescent girls that were cut as part of their initiation ${ }^{40}$. There was some opposition, however; for example, according to a UNIFEM report ${ }^{41}$ some husbands were disgruntled because they witnessed their wives attending meetings, receiving training and making decisions, which sometimes resulted in domestic violence. As a response the project increased the components involving men to ensure their approval and to protect the women. This approach has been replicated in a growing number of communities throughout the country. Tasaru Ntomonok, Catholic Secretariat, World Vision and GTZ are using this approach.

\section{Religious oriented approach}

Demonstrating that FGM/C is a practice not supported by a community's religion can be an effective approach for changing attitudes and practices. For example, the Kikuyu traditionally practised FGM/C virtually universally, but when Christian missionaries began to convert them in large numbers, messages encouraging them to abandon the practice through sermons and other interventions by the missionaries contributed to a reduction in the practice, using the argument that God made people complete and people have no right to destroy or change a God-given body ${ }^{42}$. MAP International, covering what they call the 'diocese of Kitale' which has five districts (Transmara, Mt Elgon, Turkana, West Pokot and Marakwet), uses the Church for behaviour change messages for abandoning FGM/C and other harmful traditional practices. CBOs such as CIWIT, KK Weru and Mwiwi Evangelical Fellowship in Meru North use arguments that FGM/C has no place in the Bible to educate

\footnotetext{
38 Hosken 1993

${ }^{39}$ Chege, J N; Askew, I and Liku, J (2001) An Assessment of the Alternative Rites Approach for Encouraging Abandonment of Female Genital Mutilation in Kenya, Nairobi, Kenya: Population Council

40 GTZ (2001). Addressing female genital mutilation. Challenges and perspectives for health programmes. Part I: select approaches.

${ }^{41}$ United Nations Development Fund for Women (UNIFEM). 2000. With an End in Sight: Strategies from the UNIFEM Trust Fund to Eliminate Violence Against Women, New York, NY, USA: Available at http://www.unifem.undp.org/public/tfbook/

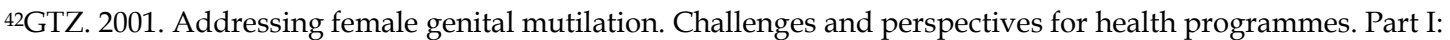
select approaches.
} 
the community. At TASARU in order to strengthen the anti-FGM/C messages, girls are involved in Church activities, and the Full Gospel Church of Kenya in Narok started antiFGM/C activities after girls started running to them for shelter. The Catholic Diocese of Nakuru (CDN) with support from UNFPA also uses the religious oriented approach against FGM/C . CDN works with the Ichamus in Baringo district.

Among some, but not all, Kenyan Muslims, religion is one of the strongest reasons given for continuing the practice. As this is a misunderstanding of the Islamic position on circumcision, some projects working with these communities have developed an approach to engage with Islamic leaders to challenge their continuation of these misperceptions and encourage them to advocate against the practice as being not supported by the religion. The Population Council, working with UNICEF, has initiated a project through which several small group discussions have been held for religious scholars from Wajir and other district in North Eastern and Upper Eastern provinces, with two scholars from non-FGM/C practicing Muslim communities acting as resource persons to lead the discussions ${ }^{43}$. This approach has two objectives:

- Critically examine the place of FGM/C in Islam by looking at the evidence fronted for the practice. Discussions went through the evidence from the ahadith ${ }^{44}$ used by the proponents and brought out the fact that these ahadith are either unrelated or weak and therefore cannot form the basis for the practice.

- Educating the community on the religious implications of practicing FGM/C so that communities question the practice as an integral component of their religious beliefs. FGM/C violates several Shariah guidelines, such as cutting healthy organs, causing harm, changing what God has created in a perfect form, and that women have a right to a healthy body and enjoyment of their matrimonial sexual relations.

This project is currently on-going, but already seems to be having some effect on religious leaders' stance on FGM/C; these gains need to be built upon and supported through further sensitization among other community groups.

Other organizations such as the UNFPA supported CIPK in Tana River district, Al-Falah in Isiolo and Womankind in Garissa use Islamic arguments against the practice. These organizations engage with religious leaders, circumcisers, women and girls to emphasize that the practice is not a religious expectation.

\section{Legal approach}

Kenya has passed a law that declares FGM/C illegal. Section 14 of the Children's Act outlaws the practice of FGM, stating that "no person shall subject a child to female circumcision, early marriage or other cultural rites, customs or traditional practices that are likely to negatively affect children's life, health, social welfare, dignity or physical or psychological development". This law has limitations in that it protects girls only up to the age of $17 y e a r s$ and does not protect women from being forcefully circumcised. By placing FGM/C within the Children's Act, it is seen as children's issue rather than being of wider significance, and therefore carries little weight. Moreover it is not a stand-alone law and one respondent said the "absence of FGM/C legislation in the Sexual Offences Bill is a lost opportunity", as it may be more effectively implemented within this framework.

43 FRONTIERS. 2007. "A Religious Oriented Approach to Addressing FGM/C among the Somali Community of Wajir, Kenya", Unpublished report, Nairobi, Kenya: Population Council

${ }^{44}$ Ahadith is the plural of Hadith: the recorded sayings and practices of Prophet Muhamad (PBUH) 
UNFPA supports FIDA in its activities in sensitization of communities and training of police officers and chiefs on Gender Based Violence (GBV) which includes FGM/C. Along side this, FIDA has developed a documentary on GBV which includes FGM/C for use during training and community sensitization. FIDA has also revised the police training manual to conform to new laws and gender considerations. FIDA has also reviewed the Convention on the Elimination of all forms of Discrimination Against Women (CEDAW) country reports highlighting key areas for improvement in laws and policies including those touching on FGM/C. CRADLE Nairobi employs awareness creation and enactment of laws to protect women or girls who wish to avoid this practice. They train community members on rights of children and provide paralegals within the community to intervene in cases where the children themselves run away or report being cut at the time of the incident or after.

The Child Welfare Association (CWA) seeks to support enforcement of the Children's Act through educating and encouraging chiefs to apprehend child rights violators and take them to the police. The Association of Media Women in Kenya (AMWIK) seeks to reach the general public through articles in magazines, newspapers and TV programs about the legal situation, and also supports CBOs working on FGM/C. AMREF mainly targets girls in and out of school.

AMWIK is involved in monitoring, implementation of laws to control FGM/C in Kenya, Tanzania, Senegal, Burkina Faso and other African countries. AMWIK mobilizes the media to highlight issues related to FGM/C, and monitors the media by checking daily newspapers to assess coverage of FGM/C. The organization also mobilizes women to work against FGM/C practice in areas where FGM/C is prevalent through addressing traditional beliefs that contribute to FGM/C.

The advantage of such legislation is that it provides a legal platform from which projects can be organized; it offers, in principle, legal protection for girls and it is intended to discourage practitioners and families through fear of prosecution. There are several disadvantages, however: it is very difficult to enforce, and so there is little motivation for communities and families to stop the practice. Moreover, introducing criminal laws against such a strongly held practice can lead to FGM/C being practised secretly ${ }^{45}$, and any medical complications are not taken to the health services for fear of prosecution ${ }^{46}$. Enactment of anti-FGM/C laws has to go hand in hand with community education and with rigorous enforcement if they are to be effective, because belief and behaviour change come about through education and dialogue, rather than through legislation alone.

\section{Human rights approach}

FGM/C is seen internationally as a violation of many women's and children's rights, such as health, to be free from gender discrimination, to life, and to freedom from torture including the inherent dignity of the person, the right to liberty and security of the person, and the right to privacy. Only by acknowledging that the subjection of girls and women to FGM/C is an act of control and gender discrimination that compromises the enjoyment of their fundamental rights and freedoms can communities begin to recognize and deal with $\mathrm{FGM} / \mathrm{C}$ as a serious violation of human rights that requires redress.

\footnotetext{
45 Njue C and Askew I (2004) op cit

46 World Health Organization. (1999). Female Genital Mutilation: Programmes to date: what works and what doesn't: a review, Geneva, Dept. of Women's Health Systems and Community Health World Health Organization
} 
The Girl Child Network, in Kajiado, uses a human-rights based approach to tackle FGM/C and sensitize the community on how this practice violates the rights of women and girls. UNICEF, in Garissa, is using this approach and includes discussion around human rights implications of FGM/C in trainings targeted at government workers such as children officers, health workers and teachers. Population Council is also incorporating discussions on this in its community education activities, not as a stand-alone approach but as part of the wider religious oriented approach by incorporating the Islamic human rights perspectives of this practice in community trainings.

\section{Intergenerational dialogue}

This listening and dialogue approach seeks to create a two-way dialogue between the community and facilitators ${ }^{47}$ to encourage discussion around the ambivalence and dilemmas which accompany the process of adapting new attitudes and behaviours. The intergenerational dialogue was originally introduced by GTZ in 2000 in Guinea as an innovative approach which sought to ask questions for which there were no right or wrong answers, to listen, and to facilitate frank discussions based on mutual respect. This is 'intergenerational' as it facilitates dialogue between different generations in communities where this is not the 'norm' and where the young and the old do not conventionally dialogue especially on sensitive issues such as sexuality.

The most important lesson learned was that persistence of the practice was not due to a lack of information, but there was a need to consider the advantages of stopping the practice against the disadvantages within a dialogue setting. The meeting of two generations (e.g. younger and older women) to discuss topical themes in their own way according to their own priorities allows participants to quickly arrive at the heart of the matter. In Kenya, $\mathrm{MOH} / \mathrm{GTZ}$ Kenya been using this approach since 2005 in Kajiado and Greater Meru, and is about to undertake an evaluation to determine its effectiveness.

\section{Promotion of girls' education to oppose FGM/C}

In some populations, for example the Maasai, FGM/C is practised immediately prior to marriage as an indicator of a girl becoming marriageable as an adult woman. Because it is done during a girl's teenage years, and not before or during puberty as is the case for many Kenyan communities, some girls are mature and strong enough to question and oppose the practice. This is not only because of fear and disagreement with the procedure itself, but also because it is normally directly associated with early marriage, which means becoming a wife and therefore having to stop schooling, becoming pregnant and having a child. When practiced on teenagers, FGM/C has also contributed towards girls choosing to give up school because they psychologically feel that they have "become a woman" and so should not be in class. In Kuria, for example, FGM/C is usually done during the December school holidays and a reduction in the number of girl children is often noticed in January.

One approach that seeks to build on this is through interventions to strengthen education for girls (and boys) in schools within these populations, the intention being to encourage them to question the practice and to actively oppose it within their own families and communities. Some programmes use arguments around the importance of education for girls and the accruing benefits to the community, such as poverty reduction in the community.

47 Bah Binta, Jeanne Manguet, Anna von Roenne, Madeleine Tolno (2003). The Intergenerational Dialogue: Experience of a 'listening and dialogue' approach to FGM/C and HIV/AIDS. Summary Report. Conakry and Poppendorf. 


\section{Supporting girls escaping from early marriage and FGM/C}

In communities like the Maasai, there is a close link between FGM/C and early marriage since they cut the girls at puberty or on the wedding day as part of the wedding ceremony. Many girls have been known to run away to avoid being cut and married. In order to increase access for rescued girls as well as ensure their retention in school, Forum for African Women Educationalists (FAWE) has built boarding facilities to accommodate 50 rescued girls at the AIC Church in Kajiado ${ }^{48}$. At present, 42 girls rescued from early marriage have found a home in the Centre. FAWE has also provided bursaries to 15 girls at the centre, while providing textbooks, exercise books and stationery. FAWE has held various activities, which have contributed to the creation of an enabling environment for girls. Through a theatre-for-development programme, targeting both the rescued girls and other girls in the school, a girls' club has been created in the school. Tasaru Ntomonok which is supported by UNFPA has rescued over 50 girls from early marriage and FGM/C in Narok district. At the rescue centre, the girls are counseled and educated about their rights and the need to stand by their decisions. They also provided with formal education.

The Child Welfare Association (CWA) reported being involved in rescuing children in danger of violence, including FGM/C, and taking them to children's homes such as Mama Ngina and Kanduyi children's homes. They also train government personnel, such as chiefs, on prevention of FGM/C, on child rights so that children can be listened to, and on children having to give consent before they are involved in such a practice. They also offer training in vocational skills and offer employment for the young person's after training.

\section{Programming strategies for encouraging behaviour change}

Traditional communications: When FGM/C is a rite of passage to adulthood, it is traditionally accompanied by pomp and pageantry in the form of song, dance and a lot of funfair. Folklore as an approach is also adopted by organizations such as FHOK, as a way of getting women and youth groups to compose song, plays, poems and skits with messages on the dangers of FGM/C. AMWIK also relies on communication through singing to pass information to communities.

Community education: Action Aid, in Mt. Elgon, reported using workshops for educating communities on the effects of FGM/C. The Catholic Diocese in Nakuru holds discussions with community groups in its churches to discuss FGM/C; women organize the meetings and through this approach are able to bring together 50 women for briefing and follow up. Presentations, speeches and poems through students are other strategies employed by these organizations, and tapes and videos highlighting such presentations are used. Presentations are mostly carried in churches and are considered outreach programmes because they are able to reach out to large groups of women and youth.

There are also publicity campaigns aimed at enhancing awareness that FGM/C is not a healthy practice. For example there is the "forum theatre in Kenya Female Advisory Organization" (KEFEADO), whereby community members perform a play portraying the brutal aspect about FGM/C. The Kenya Youth Education and Community Development Programme (KYDCEP) organize monthly youth fora in all constituencies of Laikipia and Nyandarua district where the main target is the young girls.

48 FAWE. 2003. The Quest for Quality in Girls Education: FAWE Centres of Excellence- AIC Girls' Primary School Kajiado District. Nairobi, Kenya 
Most organizations undertake community education and sensitization through organizing education seminars and public meetings (barazas). They also support community development projects that will ensure women's empowerment such as supporting women initiatives in business. The Ministries of Education and Health are involved in community education, while the provincial administrations are expected to ensure that laws against FGM/C are adhered to. Some descriptions of specific programme activities are given below to illustrate the range being implemented in Kenya.

Youth participation: Most organizations have tried to actively involve all members of the community in their programmes. Respondents stress the importance of youth participation in the success of any FGM/C abandonment effort, as peer influence is a key factor that supports many girls to willingly be cut during school holidays. In some programmes, youth educational sessions are always planned during school holidays so that they can actively participate. In Kuria, the organizations try to sensitize youth on the dangers of FGM/C, by including boys so that they accept uncircumcised women for wives when they grow up. In Garissa, boys are involved in programmes as change agents by telling them that even uncircumcised girls can be married and make good wives. This was at the request of girls; one programme officer reported that "Girls used to ask...now that you have educated us on this issue, why don't you involve the boys too..."

Advocacy: Several agencies have recruited community leaders to mobilize and educate the community members, disseminating information and carrying out advocacy activities in project sites. Seminars have been organized where different groups of participants are involved. Educational programmes have also been incorporated into the syllabuses of schools to educate students about the consequences of FGM/C, particularly in the context of raising awareness about HIV/AIDS and health practices that may increase susceptibility.

Some programmes have been advocating for ending FGM/C at the community and national levels by involving the media. This strategy is used because messages can be disseminated to large audiences and be used to trigger dialogue among community members. Mass media such as newspapers, magazines, journals, booklets, radio broadcasts, telecasts and the internet are all used to advocate against FGM/C and for empowerment of the girl child and women. Several cases have been reported through the mass media of investigations that have led to arrests, and many media houses have written extensively about the health, psychological and social issues associated with the practice. The press has highlighted research studies, the dangers of FGM/C, deaths related to FGM/C and communities' efforts to welcome young girls into adulthood through alternative rites of passage. A growing number of radio stations (some using vernacular languages) have helped address the issue. Action Aid campaigns against FGM/C and strengthens education for the girl child. Action Aid also organizes forums within schools and through churches where they talk about FGM/C to create awareness among target groups on the risks involved. With regard to parents, they try to educate them on the benefits of not taking the children for FGM/C and instead ensuring their continued education.

Public pronouncements by politicians and other opinion shapers have emerged as an important aspect of advocacy as public declarations are essential as they provide publicly binding evidence of a collective commitment in a communally identified social environment. Such public declarations seem to have the power of a declaration of a new social order that no longer accepts the practice of cutting women's genitals. Declarations can act as a means to change "customary law" which is often the stronger ruling in traditional African societies.

Integration into other programmes: The Action Times Family Care NGO in Kisii has incorporated FGM/C as a component in its HIV/ AIDS projects, through portraying the 
practice as a possible source of HIV infections. The Daraja Community in Kisii have incorporated FGM/C into its family planning activities, by arguing that FGM/C will not be acceptable on its own as the communities will think that their culture is being challenged without reason. This programme also uses a participatory approach involving stakeholders as a team, to involve people in designing solutions to problems emanating from discussions about FGM/C so that they feel they are part of the solution and not the problem.

The $\mathrm{MOH} / \mathrm{GTZ}$ anti-FGM/C programme is working through both formal structures and civil society to integrate anti-FGM/C activities into routine procedures. GTZ has a strong focus on community mobilization, providing space for inter-generational dialogues, alternative rites of passage, using the radio for broadcasting anti-FGM/C messages, networking, lobbying and advocacy. GTZ is working in Kajiado, Kuria, Narok and Meru.

UNFPA advances the rights of women and girls to exercise control over their lives and their sexuality. UNFPA funded partners have integrated FGM/C into their respective activities sexual and reproductive health activities including HIV/AIDS prevention activities. UNFPA supports the government i.e. Ministry of Gender, Culture, Sports and Social Services, and local implementing partners ( such as SAIDIA in Samburu District, Tasaru Ntomonok Initiative (TNI) in Narok District, the Catholic Diocese of Nakuru (CDN), FHOK) and the Council of Imams and Preachers of Kenya (CIPK)working to strengthen policy advocacy, enhance women's sexual and reproductive rights and access to RH information and services, increase awareness among parliamentarians and the community on women's rights including FGM/C. UNFPA also works with media to highlight RH issues including FGM/C.

A number of programmes also recognized the importance of inter-agency collaboration and networking to enhance sustainability. For example, FHOK is working with the Provincial administration, which is playing a crucial role in bringing back girls fleeing from the practice, the judiciary to interpret the Children's Act, and the District Education Office and MYWO at the community level. At the national level, the project has been networking with national and international organizations by sharing experiences as well as drawing on stakeholders who have been in the field for longer, among them MYWO and PATH. Local stakeholders in Mt Elgon are collaborating with World Vision to educate communities on a wide range of topics, including nutrition, hygiene, harmful traditional practices, girl child education, mother-girl relationships, and training young girls on alternative rites of passage and training fathers and circumcisers on sensitive issues and risks of FGM/C.

Use of research: A number of the larger organizations have conducted research studies (Population Council, PATH, MYWO, GTZ, CARE and others) and developed data collection tools to be used during sensitization to collect relevant information that can then be used for programming as well as assessing effectiveness.

Building organizational capacity: Most of the larger NGOs, such as FHOK, AMREF, World Vision and Action Aid, report having taken steps to enhance the organization's technical capacity to equip staff with the skills and knowledge needed for FGM/C programming. This includes training of mobilizers, change agents, training in counselling skills. Most of their staff are trained before being sent to the field. For the national agencies, this training is usually donor dependent. For example, CRADLE provides training for lawyers, people who work with children, and for paralegals.

Development and use of training and educational materials: A number of organizations report that they develop anti-FGM/C training materials and/or borrow materials from others. The Catholic Diocese of Nakuru develops training materials together with a number of collaborators, such as the Episcopal Conference, and they also borrow manuals from 
MYWO, Azaro from Narok, the Ministry of Health and the Ministry of Gender. CRADLE works with a paralegal network called KASUMA and they have developed a curriculum for paralegal training. CEDMARC develops its materials with their partner groups when they come together in meetings. The topics covered in the training materials vary according to the approach being used by the organization and the needs of its target audiences. For example, AMREF addresses reproductive health and FGM/C, human rights, dangers related to FGM/C, and alternative rites of passage. The Catholic Diocese of Nairobi's materials cover FGM/C, traditional practices, health implication of FGM/C, boy-girl child education, communication and life skills, peer pressure and reproductive health issues.

Most of the trainings are aimed at and involve women; girls, boys and men are hardly involved in training. Youth are not adequately involved because they do not have adequate training to enable them articulate issues against FGM/C. In Nairobi, the focus of most organizations has not been on training, the assumption being that people in the city have adequate knowledge.

All the organizations contacted are using educational materials, mostly posters, brochures, flyers, and leaflets. A group in Narok called Tasaru uses IEC materials in local languages to older men and women who do not understand English, which are useful for disseminating messages to people who do not attend anti FGM/C workshops. In Kuria, audio visual tapes are availed to schools, and especially girls' schools, in which visuals of all forms of FGM/C are shown, the intention to demonstrate the reality of the damage and harm done to discourage girls and their families from practising.

Only a few organizations are actually developing educational materials discouraging harmful traditional practices, including FGM/C. Materials have been produced in English and translated into the local language. For example, MYWO provides flyers, flipcharts and videotapes and GTZ has developed a documentary for the alternative rite of passage to sensitize the community. UNICEF has developed a series of entertaining stories told through videos, comic books, story books, radio series, travelling shows, toys, and a variety of educational materials on practices harmful to girls using a character named "Sara." Sara's tales serve as a catalyst for addressing sexual harassment, AIDS, early marriage, FGM/C, girls' domestic workload, school attendance, and related issues. These agencies have involved members of the target community in actively participating in the design of IEC messages and materials. Several organizations tend to work closely with the Education ministry, and especially with the Children's Department in every district.

Counselling of FGM/C survivors: Recently, some faith-led organizations and individual volunteers have intensified counselling services to help girls and women suffering from FGM/C. Save the Children Canada, for example, is working with local NGOs to provide counselling and Care Kenya works in northern Kenya to support programmes providing counselling services to assist women to cope. Some churches and schools are offering counselling and occasionally refuge, the aim being to provide a safe haven and to encourage the girl to overcome the psychological trauma as a result of the FGM/C. The Tasaru Girls Rescue Centre in Narok ${ }^{49}$ is known for rescuing girls in need. At the rescue centre, the girls are counselled and educated about their rights and the need to stand by their decisions. They are also provided with formal education, often through sponsorship and donations. Organizations such as World Vision in Mt. Elgon and MYWO in Narok area also running rescue centres.

49 Personal Communication, Agnes Pareiyo, P.O. Box 108 Narok, Email-aptas@Kenya web.com. 


\section{SUMMARY OF CHALLENGES ENCOUNTERED BY ANTI-FGM/C PROGRAMMES}

Cultural sensitivities and entry points for community discussion: The cultural significance associated with the practice of FGM/C makes it a very sensitive subject to address. Many families and communities are not ready to confront an age-old tradition and opt to continue with the practice, even if they understand that it is harmful. Most programmes find it difficult to identify appropriate community entry points given the sensitive nature of the practice, and are unprepared to identify entry points as it "it takes one away from their focus", or "one is forced to start from a point they did not plan to start from." In most cases, organizations do not commit resources for identifying appropriate entry points, and yet it is a necessary step to gaining community acceptance, and for ensuring that community members do not report feeling exclusion.

Entrenched religious beliefs and cultural traditions: Cultural perspectives are amongst the greatest challenges to anti-FGM/C efforts. Being deeply rooted, much advocacy for ending the practice is viewed as a way of destroying the community's culture, especially by the older generation, which greatly hampers the spread of information to the target groups. Some communities believe that FGM/C is a traditional law and if broken the woman is unclean and will be cursed: "Like if you go to a Kalenjin and tell them to stop FGM/C, you have to give them a reason why, and it is their tradition, they have to do it, if they don't the house becomes an outcast to fellow community members" (FGD, Nyandarua). Religious justification and the emergence of sects purporting to be preserving cultural practices and identity (such as Mungiki) are reversing gains made over the past couple of decades. In some areas, communities, and the girls especially, do not want to abandon FGM/C because the rite gives them a chance to receive gifts, to feast and to gain social status in the community.

High levels of illiteracy in some areas make information dissemination a challenge. Many people may not understand why a practice that has been ongoing for decades is now being discarded, irrespective of the better options being presented. Some traditional birth attendants still threaten uncircumcised women with being cut at delivery, while others refuse to assist uncircumcised women in deliver. Many people in rural areas are ignorant of the policies and laws on FGM/C. "Many will remain very stubborn even when facts have been laid bare to them. Some are ignorant of its dangers, children are the most hurt because they are forced into it and they don't participate in the decision making. Some people have never perceived that children have rights, for example, the right to make a decision on FGM/C issues. Communities have created values and respect the value more than they respect the children" (IDI, Taita Taveta).

Vast coverage areas and neglect of large populations: Difficulties in covering vast geographical areas because of limited resources and sheer inaccessibility due to poor infrastructure in the marginalized pastoral communities is a major problem. Monitoring of interventions becomes difficult and the capacity to reach children who are running away is a problem. "No one goes beyond this town (Garissa) and people who are involved at the municipality level have no capacity to reach the interior population" (FGD, Garissa). Some urban areas, and particularly Nairobi, have been neglected, yet are home to members of Kenyan communities that cut, as well as thousands of refugees from the Horn of Africa. 
Qualitative data from Eastlands in Nairobi reports inadequate awareness creation because of the assumption that FGM/C is not widely practiced in the city ${ }^{50}$.

Lack of adequate rescue homes / safety nets: Increased cases of "runaway girls" with no structures to receive them are particularly problematic during the 'circumcision months'. In some cases, religious institutions can provide sanctuary for the girls, but usually for a limited time only. Some of centres have inadequate staff and rely on volunteers with high turnover rates. The long-term sustainability of supporting rescue homes, and their effect on the girls and their relationship with their families need more attention. In some cases, some women are willing to support daughters who opt to abandon the practice, but they often lack access to resources that can be used for support.

Shifts in the practice, including medicalization: Some communities have responded to anti-FGM/C campaigns by lowering the age of cutting to prevent resistance by the girls. Effective sensitization of the risk of disease infection has led to medicalization of the practice and reductions in the amount of tissue cut.

Political support or lack of opposition: Politicians looking for support among communities that feel strongly in favour of FGM/C are either unwilling to publicly oppose the practice, or may use support for FGM/C to persuade their electorate to vote them in. For example, one politician was heard to announce "those who need money for FGM/C, come to me. This is our culture".

Gaps in laws and lack of enforcement of policies and laws: There is no clear strategy for implementation of the limited legal and policy provisions that do exist for FGM/C, such as the Children's Act and the National Plan of Action for the Elimination of FGM/C. There is reluctance among many community leaders and provincial administration staff to denounce FGM/C publicly and to apprehend and prosecute FGM/C offenders, and corruption has led to the release of culprits. In Kuria, community members use legal loopholes in the Children's Act to cut the girls as the Act only protects girls below 18 years. As a result, the community are cutting girls once they are 18 years and they cannot be prosecuted. "The chiefs and police live under fear of these elderly women who are seen to be very powerful. They do not arrest them for fear of bringing a curse to their families" (FGD, Mt Elgon).

Lack of national coordination of anti-FGM/C activities has seen duplication of efforts, as different agencies plan their activities without regard to what other partners are doing. In addition, it has made it difficult to mobilize the resources for fighting the practices as there no clear government docket or organization through which resources can be marshalled and channelled.

\section{LESSONS LEARNED ABOUT FGM/C PROGRAMMING}

1. Effective partnerships between groups with complementary expertise, at all stages of the program, facilitate effective and sustainable programmes.

2. Involving stakeholders and beneficiaries in the design, implementation, and evaluation of programmes is critical in order to develop culture-specific approaches that are acceptable.

3. Programme design and implementation should be based on sound formative research among the target communities to ensure that the expected outcomes are

\footnotetext{
50 Jaldesa G. et al, 2005, op cit.
} 
clear and activities acceptable and therefore feasible. Culture-specific community entry and education is critical.

4. Creating a change in social norms is the most crucial step for a successful behaviour change strategy. Once social attitudes held by the group as a whole are changed, FGM/C abandonment has begun and so organizations should focus on sustaining these changes and reaching others. Once the foundation of community support against the practice is established, communities can then pressurize local and national leaders to speak out against FGM/C and create policies that will help eliminate it.

5. Advocacy for girls' education is a long term strategy that seems to be promising, especially among those cultures that cut their girls later.

6. More efforts should be focused on boys and young men who are the future husbands and fathers of girls likely to be cut.

7. The media plays a crucial role in advocacy and is especially important in campaigning about violence against women generally, but care needs to be taken that appropriate messages are communicated.

8. Well-designed IEC materials can raise awareness and influence attitudes but are not sufficient for behaviour change. Theses communication materials need to be systematically pre-tested to determine whether they can achieve the changes in knowledge and attitude intended before being widely used; the medicalization of FGM/C among certain communities appears to be associated with responding to messages about the medical problems of the practice.

9. Continued prosecution can provide a much-needed jurisprudential basis for the development of the law in the area of FGM/C and can help to reinforce the message that FGM/C is neither trivial nor petty.

10. Health providers at all levels, as well as counsellors and psychologists, must be trained and supported to be able to manage medical and psychological, including sexual, complications arising from cutting in girls and women.

11. The state should domesticate and implement the international conventions that offer protection to women and uphold women's rights. Only by acknowledging that the subjection of women and girls to FGM/C is an act of gender discrimination that compromises the enjoyment of their fundamental rights and freedom can communities begin to recognize and deal with FGM/C as a serious violation.

\section{GAPS IN KNOWLEDGE AND PROGRAMMING}

- Understanding the broader social and cultural context of FGM/C: FGM/C cannot be isolated from the broader social and gender inequalities that exist within a community, and so it is essential to understand this context before developing programmatic approaches.

- Application of culture-specific understanding of FGM/C: Much is known about the practice, including why different communities are practicing FGM/C, but this culturespecific knowledge is frequently not used when strategies are developed and/or applied. For example, the Alternative Rite of Passage approach has sometimes been used even when FGM/C is not a central element of the group's rite of passage. 
- Limited knowledge on the psychological consequences of FGM/C: Research on the psychological aspects of FGM/C, including its effect on girl child education and early marriage is needed to increase understanding of the ways in which FGM/C affects girls, and women, psychologically. Such knowledge is important not only to assist in developing appropriate counselling services to address psychological problems, but also to provide information that could be used within anti-FGM/C messages.

- Better understanding of the role of religious institutions and teachings on continuation of FGM/C: Most Kenyans, regardless of their faith, are highly religious, and so a better understanding of how religious teachings and institutions (from all faiths and denominations) could be marshalled to better engage with religious leaders as advocates against the practice.

- Lack of systematic evaluations of the effectiveness of anti FGM/C approaches: As noted above, a wide range of approaches have been, and continue to be used in Kenya. Very few have been systematically evaluated, and most have minimal monitoring systems in place to document their progress. More formal evaluations are required to guide selection of successful elements of anti-FGM/C programming and to disregard or discontinue those that are ineffective, and thereby wasting scarce resources.

- Potential role of communities in law enforcement: Even within its limitations, the existing legal framework for restricting FGM/C could be more rigorously enforced. Opportunities for community courts that hold credibility and legitimacy, such as Masslaha courts among the Somali population and the councils of elders (Njuri Njeke among the Meru), should be explored, as well as means for encouraging greater community participation in monitoring a reporting cases of FGM/C.

- Focus on behaviour change and appropriateness of IEC materials: Many implementers often conduct IEC activities with a focus on awareness raising as the expected outcome, rather than on behaviour change, and consequently once awareness is raised there is no clear strategy for moving the community along the behaviour change continuum. IEC materials and activities to communicate with communities are often not research-based or pre-tested, and the production and distribution of materials becomes an end in itself. IEC materials need to be produced in local languages to make them easier for people to understand and to appreciate the nuances of the messages.

- Limited awareness of existing policies and laws, and poor enforcement: Other countries have shown that appropriately structured laws and their enforcement can enhance abandonment of the practice, and so the full potential of the existing laws and policies in Kenya need to be exploited by developing, testing and evaluating appropriate procedures that could become standard practices if proven effective. Contradictions and a lack of clarity with the existing legal provisions and procedures need to be addressed to enable them to be fully implemented.

- Lack of effective coordinating mechanisms to harmonize national efforts: Despite the huge amount of activities that have been, and continue to be, undertaken against FGM/C in Kenya, several mechanisms are lacking that would increase efficiency. These include a stand-alone and comprehensive law on FGM/C, a national mandated and recognized body for coordinating anti- FGM/C activities, capacity of implementers to conduct M\&E; and limited availability of documentation and evaluations of program approaches, strategies and lessons learnt. 


\section{COORDINATING FGM/C PROGRAMMING SUPPORT IN KENYA}

Respondents were all in agreement that there is an urgent need for a National Coordinating Agency (NCA) that could bring together all stakeholders working towards the abandonment of FGM/C in Kenya. While there was general agreement that a government ministry should host the NCA, there were differing opinions as to whether it should be the Ministry of Gender, the Ministry of Health or the Ministry of Youth. Most respondents felt that the NCA should be independent within the ministry, with adequate staffing and a government budgetary allocation to be able to function effectively in fulfilling its mandate. The views of community gatekeepers, programs managers and government officials on the role, structure and responsibilities of a National Coordinating Agency suggest that is should:

1) Coordinate all anti-FGM/C activities nationally, including ensuring budgetary allocation for anti-FGM/C activities nationally.

2) Lobby for FGM/C as key development issue through coordinating an interministry working group and making anti-FGM/C activities an integral part of the national development programme to enhance visible government commitment to improving the position of girls and women in society.

3) Lead advocacy efforts to create a supporting environment for anti-FGM/C programmes.

4) Facilitate capacity building and support for implementing organizations, service providers, including development and standardization of training materials and curricula for use by all agencies implementing anti-FGM/C activities nationally.

5) Strengthen program monitoring and support regular evaluations and documentation, and liaise with stake holders to set achievable targets.

6) Mobilize resources for FGM/C programming.

7) Work with the media and support CBOs / community groups involved in antiFGM/C campaigns, including innovative educational activities in the print and electronic media.

8) Work with police to enforce existing laws.

9) Establish network structures to strengthen synergy and collaboration among all the stakeholders, including strategic ministries and agencies and ensure their participation in programmes and activities.

10) Centralize and act as a clearing house for all IEC materials and be able to develop / assemble, pre-test, evaluate, translate and disseminate IEC materials to be used at national level, as well as variations that can be used in local languages and different cultures.

11) Lead in policy reform and legal reform to remove barriers to exercising equal rights by girls and women. It should make recommendations for revision and strengthening the National Plan of Action for the Elimination of FGM/C and implement the Action Plan effectively. It should envisage mainstreaming FGM/C concerns into gender, $\mathrm{RH}$ and population and development initiatives and making FGM/C issues central to the formulation of policies, legislations, resource allocation, and in the planning and monitoring of programmes. 


\section{ANNEX: LIST OF ORGANIZATIONS}

Action TIME Family Care (ATFC)

Action Aid International

AL Falal

AIC Kajiado Girls Primary School

African Medical Research Foundation (AMREF)

American Education and Development Program (AED)

Africa Hope

African Network for the Prevention and Protection against Child Abuse and Neglect (ANPPCAN)

Anglican Church of Kenya

Association of Media Women In Kenya (AMWIK)

ADRA Kenya

Basonga Community Health Outreach

British High Commission

Catholic Diocese of Nakuru (CDN)

Canadian International Development Agency (CIDA)

CARE Kenya

Centre for Rights Education Awareness (CREAW)

Centre for the Study of Adolescence (CSA)

Center for Minority Rights Development (CEMIRIDE)

Child Rights Advisory Documentation and Legal Centre (CRADLE)

Child Welfare Association

Children's Legal Action Network (CLAN)

Christian Community Services

Christian Children's Fund (CCF)

Christian missionary fellowship (CMF)

Church World Service (CWS)

Coalition on Violence Against Women (COVAW)

Coast Development Authority (CDA)

Community Integrated Development Project (CIPED)

Community Relief Services (CRS)

Consortium for Empowerment and development of Marginalized Communities

(CEDMARC)

Council of Imams and Preachers of Kenya (CIPK)

CIWIT (Hope for yourself, Jitengemee)

DFID

Daraja Community Based Organization

EMACK

El-Taller International

Equality Now 
Family Health Options of Kenya (FHOK)

Federation of Women Lawyers (FIDA)

Friends of Nomad International (FONI)

Full Gospel Church of Kenya

Forum for African Women Educationalists (FAWE)

German Development Cooperation (GTZ)

Health Unlimited

IPPF

International Labor Organization (ILO/IPEC)

Isiolo Youth against AIDs Program (IYAAP)

IKWIP

Juliekei

Kenyan Arab Friendship Society - National

Kenya Alliance for the Advancement of Rights of Children (KAARC)

Kenya Assembly church of Kenya

Kenya Youth Education and Community Development Programme (KYECDP)

Kenya Female Advisory Organization (KEFEADO)

Kenya Child Welfare Association

Kuria Child and Development Program (KCDP)

Konrad Adenauer Foundation

Kenya Arab Friendship Society

Lutheran Outreach

Maendeleo ya Wanawake Organization (MYWO)

MAIKOO ATE (Maasai people's program)

Maranatha Faith Based Organization

Methodist Church

MERLIN International

Ministry of Justice and Constitutional Affairs

Min. of Education Science \& Technology - MOEST

Ministry of Gender, Sports, Culture and Social Services (Department of Gender)

Ministry of Health, DRH

Ministry of Home Affairs

Muslim Consultative Council (MCC)

National Coordinating Agency for Population \& Development (NCAPD)

National Council of Churches of Kenya (NCCK)

National Council of Women of Kenya (NCWK)

NACC

Norwegian People's Aid

Northern Aid

Norwegian Embassy

Ogiek welfare community 
Oxfam

Partners for progress (PFP)

Pastoralists Girl Initiative (PLI)

PLAN International

Program for Appropriate Technology in Health (PATH)

Population Council

Practical Solution (PRASO)

Presbyterian Church of East Africa (PCEA)

Ripples International

Rural Women's Peace Link (RWPL)

Royal Netherlands Embassy

Supreme Council of Kenya Muslims (SUPKEM)

Save the Children Canada

SNV Kenya (Netherlands Development Organization)

SDA rural project

St. Martins friends of the youth

Socially organized education team (SOET)

Samaritan Purse Relief International

SIMAHO

Tigania Cultural Development Association

Tasaru Girls Rescue Center

United Nations Children's Fund (UNICEF)

United States Agency for International Development (USAID)

UNIFEM

United Nations Population Fund (UNFPA)

UNHCR

UNFPA

Volunteers children's officers Association (VOS)

Vivid Communication

Womankind Kenya (Wokike)

World Vision

Women's Rights Awareness Programme (WRAP)

World Health Organization (WHO)

Woman Concern

WAFNET

Women Department Initiative

World Relief 
For more information, please contact:

Population Council

General Accident Insurance House

Ralph Bunche Road

P.O. Box 17643

00500 Nairobi, Kenya

Tel: +25420 27I 3480

Fax: +25420 27I 3479

Email: info@pcnairobi.org

or

Ministry of Gender, Sports,

Culture and Social Services

NSSF Building, Block A, Eastern Wing

P.O. Box 16936 - 00100

Nairobi, Kenya

Tel: +254202727980

Email: genderdir@gmail.com 